\title{
Music and Sculpture, a Panacea for Combating Unemployment in Nigeria
}

\section{In the 21st Century: A Case for Entreprenuership Education}

\author{
Dr Sunday N. Nnamani ${ }^{1}$, Dr. Casmir N. Nnamele ${ }^{2}$ \\ ${ }^{1}$ Music Unit, Dept of Fine \&Applied Arts/Music, Federal University Ndufu-Alike Ikwo, Pmb 1010 Abakiliki, Ebonyi State, \\ Nigeria
}

${ }^{2}$ Fine \& Applied Arts Unit, Dept of Fine and Applied Arts/Music, Federal University Ndufu-Alike Ikwo Pmb 1010, Abakiliki, Ebonyi State, Nigeria

Received: 7 March 2019;

Accepted: 12 April 2019;

Published: 24 April 2019

\begin{abstract}
In contemporary Nigeria, a large number of graduates are turned out from the different tertiary institutions of higher learning every year. The fact is that such graduates while in the school believe that they will be out of school rigour on graduation and will soon start life as soon as they are gainfully employed. But such dreams are in most cases shattered by the non-availability of jobs for such graduates. In the light of this, a good number of people who are graduates from the different higher institutions in Nigeria roam the streets in search of non-existing jobs. This paper deals with speciality areas of music and sculpture, the advantages and benefits inherent in these areas and their roles in generating employment with the major components highlighted. For Nigeria to attain the employment generation level of the post MDGs, there is a need to put in place vocational trainings that would enhance the right input of highly skilled human resources in music and sculpture to feed the labour market for the overall growth and development of the nation.
\end{abstract}

Keywords: Music, Sculpture, Combating Unemployment, entrepreneurship education.

\section{Introduction}

Poverty is a negative term which is better described than experienced. It is dehumanizing, degrading and unimaginable to those who have experienced it. It reduces man to the lowest realm of human existence and sentences him to perpetual life of unhealthy, dirty and miserable conditions. These conditions are largely caused by unemployment. It is unusual to see people looking malnourished resulting from health and social problems. Such problems include diseases, youths restiveness, armed robbery, kidnapping, destitution, prostitution or even death. A practical example is the emergence of militants in the Niger-Delta, agitations for secession, etc in recent times where the youths are protesting against poverty, maginalization and neglect.

Poverty resulting from unemployment is a plague affecting peoples of the third World such as Nigeria and this condition denies the individuals the right to exercise or develop their full potentials as it cuts across race, nation, creed, sex, colour and religion. Poverty varies in its magnitude within our society. According to Esomonu(2002);
Seventy percent of Nigerians live below poverty level and most of them consume less than one third of the minimum required protein and vitamin intake because they cannot afford them. The failure of economic development policies and strategies in Nigeria has perpetuated poverty (unemployment). Consequently, there is increasing unemployment, underemployment, crime wave and hunger (p.xi).

This goes on to substantiate the fact that while a greater percentage of the Nigerian populace live in abject poverty, the remaining minority wallow in affluence.

\section{Definition of Terms:}

Music: Music is a phenomenon which is found in every culture, be it traditional or modern. The Encyclopedia Americana (1971) explained it as...

The art by which a composer through a performer as an "intermediary", communicates to a listener, certain idea, feelings or state of mind. Music makes use of tones singly and in combination 
with various rhythmic configurations may be subjective or objective, appealing to human intellect.

Music is a universal language of the soul which all and sundry understand amidst ethnic linguistic and dialectical differences. It has been properly diagnosed and critically looked at from divergent perspectives by many writers, scholars and music educators who are apt in the musical arena and its significant roles to mankind within the physical, spiritual, emotional, academic, religious, moral, cultural, economic and socio-political strata or framework.

Music has also been defined by Sadie (1993) as "organized sound". A musical tone is the product of regular vibration in the air and is perceived when an inner part of the listener's ear is made to vibrate in sympathy. Music has also been called both the most mathematical and the most abstract of the arts. Grolier(1997) therefore emphasized that "Music is born of emotion".

\section{The Concept of Sculpture}

Sculpture is a branch of fine art which deals with the production of what one can see and touch, that interprets the inner feelings with the use of media like wood, clay, cement, fibre mat, plaster of Paris, metals and found objects among other materials that will accept to dialogue with the sculptor. In other words, Sculpture is an art in three dimensions, Length, width, and the depth which is capable of casting shadows. This shows that anything that cast shadow is an art work and precisely a sculpture piece. Also sculpture is defined as anything created by God and man. This definition made the processes, techniques, materials and ideas in sculpture unlimited. Anything can go in and out of sculpture. Quoting Lawal (2004), this aspect of visual art is primarily concerned with aesthetics. In this case, commercial and functional parts of it is not laudable.

In view of this, it is clear that sculptors have not been out to find out some areas that could be advantageous to them. This implies that if creative boundaries of sculptors are expanded, this profession can take most youths and upcoming sculptors who are graduates to their point of survival. More so, make them self employed and fulfilled in life. Self employment is a critical factor in job creation but unfortunately unemployment has come be one of the major problems affecting growth, sustainability and development in Nigeria. In other to eradicate this, Nigerian youths need to be self employed rather than waiting to be employed especially as the established formal sector is saturated as a result of population explosion.

\section{Types of Sculpture}

Sculpture is divided into two major parts, Sculpture in the round and relief. Sculpure in the round is the type of sculpture that one can go round without obstruction, while Relief Sculpture is the type that has all the characteristics of sculpture in the round but one cannot go round it without obstruction. Such sculptures are either called low or high relief.

The three dimensional sculpture according to Lawal (2004) is called sculpture in the round. This aspect of sculpture is made from wood, stone, ivory, feather and concrete among other material that sculpture of this type will accept. Presently, this type of sculpture accepts every material available. This unlimited approach to choice of media made it possible for us to have 'new forms' of art such as mobile sculpture, light sculpture, soft sculpture, airborne sculpture, earth sculpture and etc. Even its techniques are also unlimited. In this, virtually all the details and sides are seen around the projected form.

The relief aspect of sculpture refers to sculptures which are not free standing, that is, they are not separated from their background. The background is usually of the same medium but is on a lower level than the forms. In some cases, it is made of combinations of material, we called mixed media. Here, different materials are employed in a particular piece of work and different function are assigned to them. Relief sculpture is of three types, Low ,medium or half relief and high reliefs. Low relief is also refer to as bas relief (basso- rilieve). This includes those sculptures ranging from mural in gravings to those that rise above their back groung by few centimeters. Most of them are created through intaglio technique while some are also created by direct application of materials. Even relief works are produce in inverse, sunk in to the surface instead of embossed upon it. Medium or half relief is also known as mezzo-relievo. The projection here is more than what is obtained in low relief. The forms are well defined but not to be compared with high reliefs. High reliefs are referred to as altorelievo. The projection here is more than what is obtained in low relief . The forms are well defined but not to be compared with high reliefs . High reliefs are referred to as alto- relieve, which is almost detached from the background. It is like sculpture in the round. The figures are highly projected in such a way that it looks three dimensional.

Sculpture as an aspect cum area of specialization in Fine and Applied Arts departments in institutions of higher learning is broad in scope, due to the different skills involved in it. Such skills are, modeling, casting, carving, metal forming, welding and exploration. These can appear in form of abstraction, realism and semi- realistic pieces . Lawal (2004) aptly states that aesthetic quality and relevance of sculpture to humanity have not been watered down.

Due to changes in global economy, the functional relevance of sculpture should be strengthened to meet contemporary relevance. This will improve the patronage of sculpture in Nigeria.

\section{Entrepreneurship Education}

Entrepreneurship education seeks to provide students with the knowledge, skills and motivation to encourage entrepreneurial success in a variety of settings. Variations of entrepreneurship are offered at all levels of education from the primary through to the tertiary levels of our educational system. Hornby (2006) defines entrepreneur as a person who makes money by starting or running a business especially when this involves taking some financial risks.

Music and sculpture entrepreneurship seeks to provide students with the knowledge, skills and motivation to encourage entrepreneurial success in a variety of settings. It combines creativity, theory, practicals, technology and context in a distinctive blend of teaching and learning.

Entrepreneurship is associated with different kinds of activities that have to do with the establishment and operations of business enterprise and its related activities. This may include the 
identification of investment opportunities, decision on what opportunities to exploit for profit, promotion and establishment of business enterprise. Entrepreneurship therefore is the process of organizing business or an enterprise with a view to providing services and making some profit (Njoku, 2006).

Musicians as well as sculptors have these opportunities available to them and it is just for them to make profit out of their different areas.

\section{Objectives}

It focuses on the development of skills or attributes that enable the realization of opportunity, where management education is focused on the best way to operate existing hierarchies. Both approaches share interest in achieving profit in some form.

\section{Importance of Entrepreneurship Education}

Entrepreneurship is a key driver of our economy. Wealth and a good majority of jobs are created by small businesses started by entrepreneurially minded individuals, many of whom go on to create big businesses. People exposed to entrepreneurship frequently express that they have more opportunities to exercise creative freedoms, higher self esteem, and an overall greater sense of control over their own lives. As a result of this, many experienced business people, political leaders, economists, and educators believe that fostering a robust entrepreneurial culture will maximize individual and collective economic and social success on a local, national and global scale. It is with this in mind that the government of the day had established the small and medium scale enterprises (SMEs); to prepare youth and adults to succeed in an entrepreneurial economy.

According to the United states Department of Labour in (http:www.doi.gov/odep/pubs/fact/entrepreneurship.htm of 31st March, 2016;

Entrepreneurs drive America's economy, accounting for the majority of our nation's new job creation and innovations. According to the U.S. Census Bureau's 2002 survey of Business owners, self-employed individuals who have paid employees operate three fourths of U.S. Businesses. The U.S. Small Business Administration reports that America's 25.8 million small businesses employ more than 50 percent of the private workforce generate more than half of the nation's gross domestic product and are the principal source of new jobs in the U.S. Economy.

\section{Benefits of Entrepreneurship Education}

Entrepreneurship is an employment strategy that can lead to economic self sufficiency for young people within the age bracket of $18-25$ and beyond. Self-employment provides young people and their families with the potential to create and manage businesses in which they function as the employer or boss rather than merely being an employee. Oftentimes, the government through the Central Bank via the Industrial Promotion Schemes provides technical and financial supports which can serve as a safety measure that may decrease the risk involved in pursuing self-employment. The youths who are interested in becoming entrepreneurs often realize that it will not be an easy task. But entrepreneurship education offers a reliable solution, it seeks to prepare particularly the youth to be responsible enterprising individuals who become entrepreneurs or entrepreneurial thinker by immersing them into real life learning experiences where they can take risks, manage the results and learn from the outcomes.

Through entrepreneurship education, young people learn organizational skills, including time management, leadership development and interpersonal skills. All these are highly transferable skills sought by employers. According to Logic Models and Outcomes for Youth Entrepreneurship Program (2001) a report by the D.C. Children and Youth Investment Corporation, other positive outcomes include:

- Improved academic performance, school attendance; and educational attainment.

- Increased problem-solving and decision-making abilities

- Improved interpersonal relationship, teamwork, money management and public speaking skills

- Job readiness

- Enhanced social psychological development (selfesteem, ego development, self-efficacy and)

- $\quad$ Perceived improved health status

\section{Music Entrepreneurship}

The mission of music entrepreneurship is to empower every music student with the skills and mindset to succeed in the professional world. In music we treat entrepreneurship as an altitude that infuses every subject from bios to business and beyond. A music entrepreneur is the business man or woman, organizer or director of a music business or a music enterprise. He packages his resources, music abilities and takes advantages of them by way of creating a business environment that will lead him to career profit.

Several business organizations exist in our society and these organizations are established principally for the purpose of making profit. However, not much of Music business organizations are established in music area for the purpose of making profit; not to talk of most musicians becoming entrepreneurs. Probably most musicians may not be aware or understand that they have what it takes to become successful entrepreneurs. For a music minister to gain ground in the business sector he must understand the principles of business. This is prominent for musicians who operate within the church circles.

\section{Eradicating Poverty in Nigeria through Music}

Poverty as a multidimensional problem causing misery, hunger, starvation, crime disease and death cannot be eliminated completely but may be reduced to the barest minimum (Oluwonomi, 1997). Since paying people for just working cannot alleviate poverty, any poverty alleviation programme should be geared towards skill acquisition which will make those concerned to be self-reliant and not depending on the government for nonexisting jobs.

Anuforom (1984) rightly observed that music education has as one of its objectives. "The development of the child's talent, physical skills as well as the acquisition of specific vocational training that could enable one develops healthy altitude towards honest labour". Reasonably the acquisitions of these skills are essential ingredients for the building of self-reliant individuals capable of employing themselves. There are many ways through which music education can make one self-reliant thereby minimizing the problem of 
unemployment and thereby helping in the eradication of poverty in Nigeria. These include;

(i) The establishment of personal music studios for music productions. Through this, the music graduate will become a producer, arranger or a Music Director.

(ii) $\mathrm{He} / \mathrm{She}$ can also establish a music band, thereby engaging in musical performances to earn a living. Many renowned musicians within and outside the shores of this country have succeeded in life through private ownership of bands;

(iii) One can become self-employed by engaging in the coaching and grooming of church choirs and orchestras.

(iv) Unemployment can be curbed through the establishment of private schools of music and by becoming a music promoter.

(v) Through the knowledge of music education, one can become an instrument or music technologist. This engaging in the designing fabrication, repairs and maintenance of musical instruments.

(vi) When the skills in music education are acquired, it enhances productivity thereby helping in the reduction of poverty

\section{The Place of Sculpture in Job Creation}

When world leaders from 189 nations met at the United Nations Headquarters in New York in September, 2000, they pledged allegiance to the new global partnership to achieve the following eight Millennium Development Goals (MDGs) by 2015: They are;

- $\quad$ Eradicate extreme poverty and hunger

- Achieve universal primary education

- Promote gender equality and empower women

- $\quad$ Reduce child mortality

- Combat HIV/AIDS, malaria and other diseases

- Ensure environmental sustainability and

- Develop a global partnership for development

The process of eradicating extreme poverty and hunger happens to be the first of the MDG goals but unfortunately according to the Food Security Handbook of 2014, the situation is getting worse especially in Nigeria.

The general attitude to vocational and technical education is such that the society seems to have a discriminatory attitude to vocational and technical education. Ilemobade and Aderoba (1994) link this discriminatory attitude to the transfer of British mentality to Nigeria. It is erroneously believed that vocational and technical education and related programmes are for those who cannot cope with academic pursuits and that the manipulative activities are for the illiterate or not so bright members of the society. Olaitan (1996) commenting on this states that "the dignity of labour which characterized traditional African education has given way to a disdain for blue collar jobs and this development appears to be a major fallout of the British type of liberal education which Nigeria received as part of her colonial legacy.

Correlating with the above assertion, Ogunyemi (1997) states that;

It must be realized that if we as a nation scorn excellence in plumbing because it is a humble activity and tolerate shoddiness in philosophy because it is an exaltation activity, we shall neither have good plumbing nor good philosophy and neither our pipes nor our theory will hold water.

Acquiring vocational education in sculpture will make the individual to become self-reliant and more responsible. According to Fafunwa (1974), "the purpose of education in any society is to prepare the young one for adulthood and to provide them with the basic skills necessary for effective participation in the society which can earn them good livelihood". Of a fact, the curriculum designed for the teaching and learning of sculpture in our schools is in consonance with the ideas formulated by Fafunwa as was stated above. Therefore, the skills acquired as a result of the theory and practice of sculpture is enough to make a sculptor earn his living and also become very comfortable as an individual. If the correct education in sculpture is embraced, there is the tendency that joblessness will be greatly reduced. Below are some of the aspects of sculptures that can be ventured into to be self reliant rather than going about on the streets of Nigeria in search of nonexisting jobs.

\section{Metal sculptures}

Metal sculpture is defined as the organization of metal junks together to form a concept. Good enough that such metal sculpture when purchased fetches the metal sculptor huge sums of money. Yet such patronage is very rare. Sculptors should broaden their horizon and delve into the production of metal doors, windows and gates and the fabrication of other types of household wares. Yet, if doors, gates and all the products are produced with artistic concepts as motif, they will attract more patronage than that of the road side welders that produce theirs without aesthetic consciousness. If the products of these road side welders are been patronized by the general public. We are sure that an academically trained sculptor from an institution of higher learning with the required skills and aesthetic qualities who ventures into such a business outfit will make serious impact on this generation.

\section{Integrating Sculpture into Architecture}

Now, there is the need for sculptors to be awakened to the realities of life by delving into exploration which is prominent in the $21 \mathrm{st}$ century. Architectural works are bettered if sculptures are integrated into it as an integral part. For instance the use of plaster of Paris to create designs on ceilings of a house and the use of cement to create images in relief around the pillars or walls of architectural forms is a source of revenue for the entrepreneurial sculptor. Even creative metal protectors and rails, balusters and water fountains are sources of survival for sculptors when integrated with architecture.

Other functional items which the sculptor can create to earn a living are flower pots of various designs digressed from the conventional flower pots. Several pots can be casted out of one mould bearing animal motif. In addition, designing and casting of concrete interlocks for the aesthetics of architectural surroundings gives hope to sculptors.

\section{Computer Designs for the Music and Sculptor Entrepreneur.}

The 21st century has had a lot of developments in the industrial sector. The music and sculptor entrepreneur should cue into them 
in order to be relevant to the society. These include computer designing soft wares such as Sibelius and Finale for music and auto card for the sculptor.

\section{Requirements}

For a sculptor to be self reliant, the following materials and tools cum skills are needed.

\section{Art Studio}

An art studio is required for a sculptor to operate. According to Portchmouth (1971), "studio is an environment where ideas and materials continually reshape each other and where related activities of all kinds can be carried out". He further stressed that the studio is also a store for materials, tools and equipments that provides multiple activities in the creative process that involves the use of tools and materials.

\section{Start and Weld Machine}

A start and weld machine and a stand-by generator are needed by a sculptor to avoid disappointments from the public power supply. Added to these are some packets of electrodes.

\section{Finance}

A sculptor needs some finance to be able to establish his business outfit. Availability of finance will however bring all the other necessary materials, tools and equipments in place. Other materials are tools such as spatula, mallet, hammer, handsaw, hand trowel, pipes, rod, clay, cement, plaster of Paris, chisels, etc.

\section{Areas of Specialization in Music}

Music entrepreneurship entails a world of great career choices. The area of specialization includes the following:
a. Performance (Singing, Instrumentation/Orchestration, conducting)
b. Music Theory (Composition, Song writing and General training)
c. Music Technology (Sound engineering, and music instrument technology)
d. Music Business Management (Events Management, Music Marketing, Ensemble and Artiste Management, Cultural Tourism)
e. Media and Communication (Music Publishing, Music Journalism, Film Music, etc).

\section{Requirements for the Music area}

A music entrepreneur requires a music studio fully equipped with a digital piano with synthesizer, cameras, and sound recording engineering equipments, tools for the repair of various types of musical instruments and for the construction of others.

Of a fact, finances are needed for the take off of this venture.

\section{Role of Music and Sculpture in Generating Employment}

Since music and sculpture are digestible mediums of communication and aesthetics, they are the most effective medium of cultural exports by individuals and groups which will result into economic benefits. Here they involve the processing and distribution of music and sculptor products, placed in material forms for the consumption of the general public. All these can then be translated into economic benefits that generate employment. Anuforom (1984) rightly observed that music has as one of its objectives ,"the development of the child's talent, physical skills as well as the acquisition of special vocational training that could enable one develop healthy attitude towards honest labour". The acquisitions of these skills are essential ingredients for the building of a self-reliant individual capable of employing himself.

\section{Conclusion}

Economically, the entertainment and aesthetic industries of which music and sculpture belong are very strong elements, vital, viable and rich aspects of culture all over the world. Musicians and sculptors will be among the highest revenue earners all over the world if they cue adequately into the trend of things in the $21 \mathrm{st}$ century. Through this, they will be able to circulate money in the society thereby providing a lot of opportunities for the young to engage in self-enterprise and self-employment.

\section{References}

[1] Anuforom, H.U. (1984). The Role of Music in Traditional Education. A paper presented in the Conference of Music Educators, Alvan Ikoku

Federal College of Education, Owerri.

[2] Esomonu, N.P. (2002). Poverty and Poverty Alleviation Strategies in Nigeria: The Role of Education.

Journal of Women in Colleges of Education (JOWICE) Vol. 6 ppxi-xii

[3] Encyclopedia Britannica (1971). Britannica Press Incorporated. Vol. 24

[4] Fafunwa, A.B. (1974). History of Education in Nigeria. London: George Allen and Unwiin.

[5] Food Security Handbook (FAO)(2014). Millennium Development Goals Booklet

[6] Grolier, J. (1997). The Encyclopedia American International. Library of Congress Cataloguing.

[7] Hornby, A.S. (2006). Oxford Advanced Learner's Dictionary of Current English. Oxford University Press. London: page 489

[8] http://www.doi.gov/odep/pubs/fact/entrepreneurship.htm. 31st March 2016, page 6 .

[9] Ilemobade, A.S. and Aderoba, A.A. (1994). Technology Education at Tertiary Level. A lead paper presented at the 17th Annual Conference of the

Nigerian Association of Teachers of Technology, Offa.

[10] Lawal, L.A. (2004). The Concept of Art, Zaria: Mibof Publishers.

[11] Logic Models and Outcomes for Youth Entrepreneurship Programs, DC Children Investment Trust Corporation (2001).

[12] Millennuim Development Goals' report (2015). United Nations Report

[13] Njoku, C.V. (2006). Small Business Management and Entrepreneurship. Ambix Printers Nigeria, Owerri: Imo State.

[14] Ogunyemi, G. (1997). Technology Education and the Exceptional Children, Technology Education 
Review. A Journal of School of Technical Education, F.C.E. (T.), Akoka, Vol. 1

[15] Olaitan, S.O. (1996). Vocational and Technical Education in Nigeria and other Countries (A Comprehensive Analysis). Onitsha: Noble Graphic Publishers.

[16] Oluwononi, G.D. (1997). Towards a Sustainable Programme for Poverty Alleviation in Nigeria. Proceedings of NES 1997 Annual Conference. Ibadan: University Press. Pp 475 - 477

[17] Portchmouth, S. (1971). Secondary School Art Studio. London: Vista

[18] Sadie, S. et al (1993). The Cambridge Music Guide. New York, Cambridge University Press. 